\title{
EUROPEAN COUNTRYSIDE - EDITORIAL
}

\author{
Milada Št’astná ${ }^{1}$ Antonín Vaishar²
}

\begin{abstract}
EUROPEAN COUNTRYSIDE is defined as an international on-line scientific journal in the branch of rural development. It publishes first of all theoretical and methodological articles, dealing with multi-functional development of countryside, articles related to regional aspects of rural development and with problems of individual branches connected with the countryside. EUROPEAN COUNTRYSIDE is a journal supporting European processes of integration, collaboration of experts from European countries and the idea of Europe of Regions. EUROPEAN COUNTRYSIDE deals with problems of European countryside - although general and/or theoretical problems of rural research from other continents are welcome. Widening of the European Community and common agricultural policy put a joint future ahead of the rural development in whole Europe. Our journal welcomes articles from different disciplines dealing with the countryside having in mine conceptions of sustainability and locality: ecology of rural landscape, rural sociology, demographic development of rural regions, human resources, gender, multifunctional development of countryside, role of agriculture and other branches, rural and agro-tourism, geography of rural micro-regions, problems of rural borderland, rural settlement, small towns as rural centres, rural planning and architecture and other aspects of rural development. The publishing in EUROPEAN COUNTRYSIDE is open for all experts from universities, scientific institutions and other workplaces of investigation. The authors will pay symbolic amount for the publication of their papers. We go out from the presupposition that a majority of results arise within different grants projects where publication costs are an integral part of the budget. Other expenses connected with publishing of EUROPEAN COUNTRYSIDE are covered by the MUAF Faculty of Agronomy. On the other side, the papers published in EUROPEAN COUNTRYSIDE will be free accessible to all potential readers through the net. By such a way we hope in better quotation of individual papers and increasing value of the papers and their authors. Additionally, professional way of publishing helps to complete this aim.
\end{abstract}

Key words: countryside, rural development, rural landscape, rural sociology, rural geography, rural planning, Europe

Souhrn: EUROPEAN COUNTRYSIDE je definován jako on-line mezinárodní vědecký časopis v oboru rozvoje venkova. Publikuje především teoretické a metodologické př́spěvky vztahující se k polyfunkčnímu rozvoji venkova, články, vztahující se k regionálním aspektům rurálního vývoje a k problémům jednotlivých oborů, spojeným s venkovem. EUROPEAN COUNTRYSIDE je časopisem, podporujícím evropské integrační procesy, spolupráci odborníků evropských zemí a myšlenku

\footnotetext{
${ }^{1}$ Ass.Prof. Milada Št’astná, PhD., Department of Applied and Landscape Ecology, Mendel University of Agriculture and Forestry Brno, Zemědělská 1, 61300 Brno, Czechia, e-mail: stastna@mendelu.cz

${ }^{2}$ RNDr. Antonín Vaishar, CSc., Department of Applied and Landscape Ecology, Mendel University of Agriculture and Forestry Brno, Zemědělská 1, 61300 Brno, Czechia, e-mail: antonin.vaishar@uake.cz
} 
Evropy regionů. EUROPEAN COUNTRYSIDE je zaměřen na problémy evropského venkova, ale přivítá i teoretické nebo obecné články, týkající se rurálního vývoje i z ostatních kontinentů. Rozšiřování Evropské unie a společná zemědělská politika před nás staví společný problém rozvoje venkova v celé Evropě. Náš časopis vítá články z různých oborů zabývajících se venkovem přičemž zdůrazňuje koncepce udržitelnosti a lokalizace: ekologie venkovské krajiny, sociologie venkova, demografického vývoje venkovských regionů, lidských zdrojů, problematiky rovných př́ležitostí žen, multifunkčního rozvoje, úlohy zemědělství a dalších ekonomických odvětví, venkovského cestovního ruchu, geografie venkovských mikroregionů a malých měst jako jejich středisek, problémů venkovského pohraničí, venkovského osídlení, venkovského urbanismu a architektury a dalších aspektů rozvoje venkova. Publikování v EUROPEAN COUNTRYSIDE je otevřeno všem odborníkům z univerzit, vědeckých ústavů a dalších výzkumných pracovišt'. Autoři budou platit symbolickou cenu za publikování jejich článků. Vycházíme z předpokladu, že většina príspěvků bude vycházet z grantových projektů, v nichž jsou publikační náklady integrální součástí rozpočtů. Ostatní náklady, spojené s vydáváním EUROPEAN COUNTRYSIDE jsou pokrývány Agronomickou fakultou MZLU v Brně. Na druhé straně, príspěvky, publikované v EUROPEAN COUNTRYSIDE budou volně přístupné všem potenciálním čtenářùm prostřednictvím internetu. Věříme, že touto cestou zvýšíme podstatně citovanost jednotlivých príspěvků a hodnocení článků a jejich autorů. Splnění tohoto cíle napomůže profesionální způsob publikování.

Klíčová slova: venkov, rozvoj venkova, venkovská krajina, sociologie venkova, geografie venkova, venkovské plánování, Evropa

\section{Aim and Scope of the Journal}

Earlier, the investigation of countryside was connected mostly with the agriculture. The postindustrial society with the process of counter-urbanisation turned the situation basically. At the present time, the attention is paid more and more to the countryside as a multifunctional space. In this connection, it turns to be a subject of a multidisciplinary and relatively complex research. Consequently, rural development has been established as a new educational and scientific program in many European agricultural and life sciences universities.

Mendel University of Agriculture and Forestry Brno (MUAF) adopted rural development as one of subjects of the master study five years ago. Due to obtained experience, we feel the necessity to establish a special journal devoted to the investigation of countryside. This decision is accompanied with an intention to create a periodical of responding quality. It means to publish a reviewed international journal in English which could aspire to be a dignified part of the international community of rural researchers.

After some discussions, following aim and scope of the journal were determined: we want to establish a medium for exchange of scientific information between rural researchers from different countries and different disciplines. We also intend to create a possibility for rural specialists including PhD. students to present their projects, ideas, results and teams. Our aspirations are directed to a concentration of people and workplaces around the periodical. Our internal goal consists of a founded team able to ensure all activities connected with the publishing of the international journal.

It is presupposed that EUROPEAN COUNTRYSIDE will deal preliminary with problems of European countryside - although general and/or theoretical problems of rural research from other continents are welcome. On the other side, European countryside is historically and naturally pre-conditioned feature, different from the countryside in other continents with specific problems and challenges.

Our journal arises in one of post-socialist countries. We offer additional occasion to publish to rural specialist from the part of the world which was 40 years behind the iron curtain. On the other side we do not create the periodical only for them. On the contrary, we have in mind a confrontation of ideas from both the parts of Europe. Widening of the European Community and common agricultural policy put a joint future ahead of the rural development in both parts of 
Europe. We suppose that the globalisation will be more important than post-socialist aspects. That is why we think about European countryside.

Our journal welcomes articles from different disciplines dealing with the countryside having in mine conceptions of sustainability and locality:

- Ecology of Rural Landscape

- Rural Sociology, Demographic Development of Rural Regions, Human Resources, Gender

- Multi-functional Development of Countryside, Role of Agriculture and other Branches

- Rural and Agro-tourism

- Geography of Rural Micro-regions, Problems of Rural Borderland

- Rural Settlement, Small Town as Rural Centres

- Rural Planning and Architecture

- Other Aspects of Rural Development

The journal is only a part of a more complex system of activities. It is connected with biennial conferences EURORURAL organized by the Department of Applied and Landscape Ecology of MUAF. We offer to the participants of the Conference to publish their papers in a egularly reviewed on-line journal widely accessible. The journal will also serve as a dissemination tool for research projects tackled in collaborating Institutions. The project of the $7^{\text {th }}$ EU framework DERREG (Development of Europe's Rural Regions in the Era of Globalization) is the first example.

\section{Editorial Policy}

The Statutes of EUROPEAN COUNTRYSIDE define it as an international on-line scientific journal in the branch of rural development. It publishes first of all theoretical and methodological articles, dealing with multi-functional development of countryside, articles related to regional aspects of rural development and with problems of individual branches connected with the countryside. Papers focusing on individual agricultural or ecological disciplines without clear connection to the countryside will not be accepted.

EUROPEAN COUNTRYSIDE is a journal supporting European processes of integration, collaboration of experts from European countries and the idea of Europe of Regions. The publishing in EUROPEAN COUNTRYSIDE is open for all experts from universities, scientific institutions and other workplaces of investigation no matter of their nationality, ethnicity, sex, political orientation. Papers, containing defamatory statements, discriminatory text or papers tending to a support of xenophobic mood will not be accepted. Technical criteria, first of all scientific quality, level of language and completeness are decisive for acceptance of individual articles.

There is no claim for acceptance of papers. The Executive Board decides about the acceptance and its decision is definitive. In the case when the submitted paper is found complete and conformed with the aim of the journal, the Executive Board appoints two independent reviewers. The reviewer must not be from the same institution as the author, at least one reviewer has to be from outside of the Executive Board and reviewers have to be from different workplaces. The identity of reviewers is confidential in the course of the review process. After acceptance the paper for print, the names of reviewers are made public by suitable way.

If reviewers raise remarks, the author is asked for a standpoint or improving the paper. If the author does not agree with some of the remarks, the Executive Board decides whether it accepts the author's standpoint, refuses the paper or asks for an additional review. After the positive clarification of all standpoints and after the positive evaluation of the language editor, the Executive Board decides about acceptance the paper in print and inserting into the respective number. The author is informed about the final decision. In this moment, the Executive Board can make the confirmation about the acceptance of the paper on request of the author. The author is also informed without delay in the case of non acceptance of the paper. The record about all the steps concerning individual papers is kept and saved for a period at least five years. 
We decided to establish an on-line journal, involving following publication strategy. The authors will pay symbolic amount for the publication of their papers. We go out from the presupposition that a majority of results arise within different grants projects where publication costs are an integral part of the budget. Other expenses connected with publishing of EUROPEAN COUNTRYSIDE are covered by the Faculty of Agronomy. On the other side, the papers published in EUROPEAN COUNTRYSIDE will be free accessible to all potential readers through the net. By such a way we hope in better quotation of individual papers and increasing value of the paper and their authors.

Additionally, professional way of publishing helps to complete this aim. The Polish company VERSITA will help us to incorporate the journal and its papers into different index services.

There are more European journals dealing with problems of the countryside. Let us named Journal of Rural Studies published by Elsevier or Sociologia Ruralis (Blackwell). Both of them fall within excellent journals and we take it into consideration. On the other side, we want to offer larger space for collaboration between experts from Eastern and Western Europe. It would be great to overcome some mutual unbelief that it is almost impossible for authors from Eastern Europe to publish in the West. One of the causes of misunderstanding could be the fact that papers from the West are more theoretically directed whereas papers from the East are more empirically based.

There are also many journals dealing with individual aspects of rural problems (e.g. sociological journal Eastern European Countryside issued by University of Toruń). In principles, the competition is perceived positively as an inspiriting and motivating tool. We extend also a possibility to spread papers among more journals. (Individual experts publish more papers yearly and it is not very suitable to publish them in the only periodical.) We offer on-line access and consequently higher probability of quotation the papers, the speed (following the deletion of the whole package connecting with print), friendly access for authors.

\section{Advisory Board, Executive Team, Realization Group}

The publication of the Journal asks for efforts of a relative big group of people. The team is divided into three groups with different tasks and methods of work but with the common responsibility.

Advisory Board of EUROPEAN COUNTRYSIDE consists of foreign experts representing individual scientific branches and European regions as much as possible. The aim of the Advisory Board is to supervise the conceptual line of the Journal, to advise in conceptual questions, to represent the Journal in their domains, to attract new authors and reviewers.

At the present time, the Advisory Board has following members: Jerzy Bański (Stanislaw Łeszczycki Institute of Geography and Spatial Organization, Polish Academy of Sciences Warszawa), Beni Bar-Yosef (Agricultural Research Organization Bet-Dagan), Bálint Csatári (Centre for Regional Research, Hungarian Academy of Sciences), Josef Etzinger (University of Natural Resources and Applied Life Sciences Wien), Elisabete Figueredo (University Aveiro), Costela lordache (University Craiova), Elke Knappe (Leibnitz Institute of Regional Geography Leipzig), Roderick Lawrence (University Genéve), Danny Markus (US Department of Agriculture), Marie-Claude Maurel (CEFRES Prague), Eileen O’Rourke (University College Cork), Hannes Palang (Tallinn University), Bas Pedroli (Alterra Wageningen), Marina Pintar (University of Ljubljana), Antonio Raschi (CNR Firenze), Peter Spišiak (Komenský University Bratislava), Antoni F. Tulla (Independent University of Barcelona), Michal Woods (University of Wales in Aberytswyth).

Executive team will manage the concrete work, organize the evaluation process, complete individual issues, tackle individual problems. It consists of Czech experts who are able to participate in the meetings regularly and to consult problems face to face. The team consists of following people: M. Št'astná (editor-in-chief), A. Vaishar (executive editor), P. Spurný (vicedean for the research and science), F. Toman (head of the Department ensuring the publishing of the Journal), A. Buček (MUAF Brno, Faculty of Forestry), J. Knotek (MUAF Brno Faculty of Agronomy), Z. Kulhavý (Research Institute for Soil and Water Conservation Pardubice), P. Maříková (Czech Agricultural University Prague), S. Miškolci (MUAF Brno, Faculty of 
Regional and International Studies), H. Mrázková (MUAF Brno Faculty of Agronomy), R. Perlín (Charles University Prague), A. Salašová (MUAF, Faculty of Horticulture), V. Svobodová (MUAF, head of the Editorial Centre), M. Štolbová (Research Institute of Agrarian Economy Prague), P. Trnka (MUAF Brno Faculty of Agronomy), J. Zapletalová (Institute of Geonics, Czech Academy of Sciences).

The Realization Group is a small efficient team giving to individual issues their final fashion. It consists of the technical editor (M. Tichá), the language editor (N. Mocková), the graphical editor (M. Flekalová) and the librarian (J. Pokorná).

\section{Advanced Authors and Possible Readers}

As follows from the Statutes, the publishing in EUROPEAN COUNTRYSIDE is open to all experts dealing with problems of European countryside from different viewpoints. It is an occasion to publish papers presented at scientific conferences, seminars and workshops. It is known that value of conference proceedings within evaluation of institutions and individuals is much lower than reviewed publication in a scientific journal. Organizers of scientific events have a possibility to submit the papers to our Journal.

Publishing results of different grants projects is a precondition of their successful evaluation. EUROPEAN COUNTRYSIDE gives an efficient possibility to the scientists who are responsible for grants projects to disseminate their findings. PhD. students prepare their thesis with a great strain. Publication activities in reviewed journals are a part of their duties. But the publication in EUROPEAN COUNTRYSIDE does not serve for the satisfaction the duties only. The projects, workplaces and individuals pass by the publication in our Journal into the world of exchange of scientific information and contacts which are usually crucial for their scientific future. The on-line form opens to authors wide space of scientific information supported by index services and electronic searching.

Of course, the Executive Team will ask prominent scientists dealing with rural affairs for substantial theoretical and methodological papers. We presuppose to have one mono-thematic issue paying attention to an important or topical rural problem per year as well.

The access to individual issues is free for anybody who is connected to internet. It performs relatively wide sphere of searching, reading, application, utilization and quotation of papers. Individual indexing services (starting with SCOPUS) make the searching easier. We endeavor to help by means of information about the Journal and individual issues disseminated by electronic way using the prepared mailing list which will be regularly updated. Experts dealing with rural problems, students of all levels, central, regional and local authorities are among possible readers. We know that many people prefer classical printed version of papers so far. But in our opinion, the situation will turn more and more to electronic documents enabling comfortable searching of papers.

\section{Publisher}

Mendel University of Agriculture and Forestry Brno (MUAF) can pride itself on the longest history of agriculture and forestry studies in Central Europe. It was established in 1919 as the University of Agriculture in Brno. Its constitution completed the long term effort to institute an agricultural university in Moravia, which has, from time immemorial, held an important post among the countries with the most developed agricultures in the Central Europe. Since its establishment, it has undergone a range of structural as well as curricula changes, and provided top quality education to more than 20,000 agricultural engineers, 6,500 forestry engineers and 5,500 engineers of economics so as to be employable in a variety of spheres of the national economy and the economic practice.

The University is divided into five colleges. Faculty of Agronomy, Faculty of Forestry and Wood Technology, Faculty of Business and Economics, Faculty of Regional and International Studies and Institute of Lifelong Learning are all located in Brno. Faculty of Horticulture is situated in Lednice. The total number of students enrolled at all five faculties was 10,817 in 2008/2009. The university has accredited study programmes with 25 Bachelor's fields of study, 12 study 
programmes with 27 follow-up Master's fields of study and 19 study programmes with 29 postgraduate fields of study.

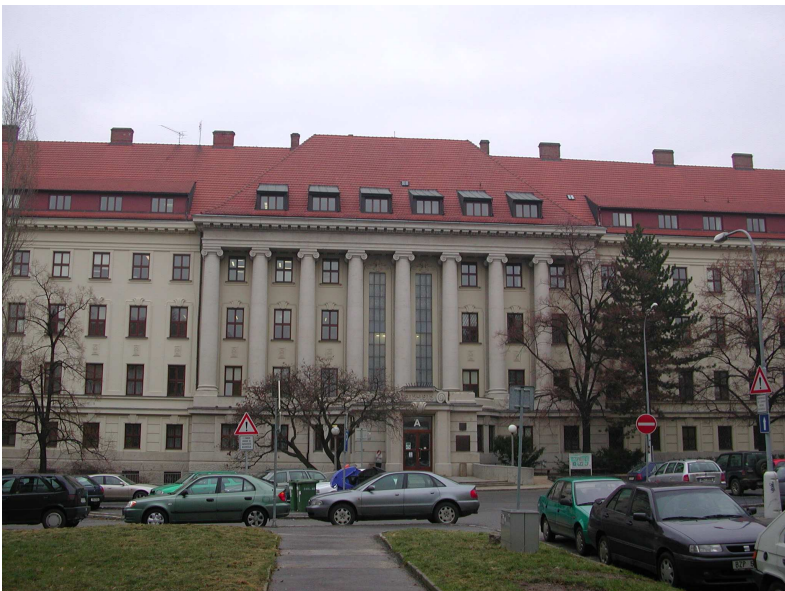

Fig 1. MUAF main building built in 1919

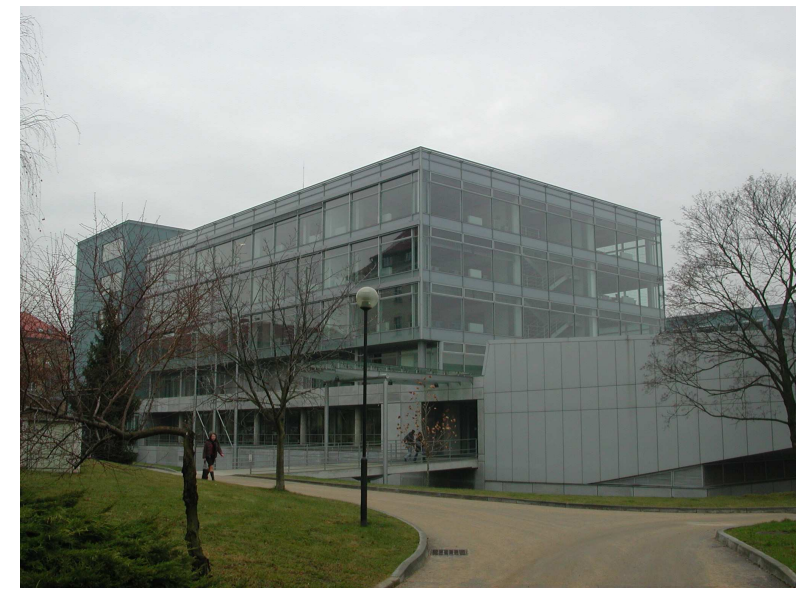

Fig 2. MUAF " $Q$ " building where the UAKE seats

The research programme of the University follows the trends in contemporary development of the fundamental scientific fields, biology in particular, and their application in agricultural, forest, horticultural and economic sciences. In compliance with the outcomes of the Common agricultural policy of EU, the university's priority is the topics concerning multifunctional agriculture and forestry, and the implications of their production and outside production functions while shaping the landscape and developing the countryside.

In order to train students, conduct experiments and verify theories in practice, the university disposes of the University agriculture enterprise in Žabčice and the University forest enterprise Masarykưv les in Krttiny. Both the Botanical garden and the Arboretum frequently serve the teaching purposes.

The Department of Applied and Landscape Ecology (UAKE) was established in 1990 at the instance of Professor V. Vaníček with the name Department of Landscape Ecology, as the first and for the long time the only one university's workplace with this name in the Czech Republic. The first head of the department (for the 12 years) had been doc. Ing. Jiři Pall, CSc., since the $1^{\text {st }}$ September 2003 up to now Prof. Ing. František Toman, CSc is the Head. After restructuring and moving to a new place in the pavilion $Q$ the Department nowadays has 12 academic employees and 15 technical and administrative employees. External employees from research institutions cooperate as well.

The Department provides teaching at all faculties of MUAF, but mostly in bachelor and master study programs on Faculty of Agronomy called Agricultural Specialization. Bachelor field of study include subjects Land Reclamation, Protection and Utilization and Agroecology. Master field of study consists of subjects Agroecology, Rural development, Waste Biotechnology and Management. The Department ensures also a doctoral field of study: Agroecology. All the fields of study arose in reaction on changes of agriculture and needs from practice. Interest overcame expectations. In the latest years the number of applications for studying Agroecology has been the highest among all fields of study offered by Faculty of Agronomy.

The research is concentrated in following spheres: Landscape Ecology and Environmentalistics, Landscape Engineering, Water Management, Waste Management and Cleaner Production. Rural Development is next research sphere which starts to develop. EUROPEAN COUNTRYSIDE is one of tools supporting its development.

\section{EURORURAL '08 Conference}

The first volume of EUROPEAN COUNTRYSIDE is partly formed by papers presented at the $1^{\text {st }}$ Moravian Conference on Rural Geography "Investigating European Countryside" which took place at the Mendel University of Agriculture and Forestry Brno in the last week of August 2008. In the Conference participated 55 persons from 16 countries of Europe, America and Asia. 
There were 40 papers and 14 posters presented. The collection of abstracts (Vaishar, Zapletalová, eds. 2008) contains 60 issues.

The excursion was directed to rural landscapes of Southern Moravia. The participants climbed the Pavlovské vrchy Hills where had a possibility to observe controversial Nové Mlýny waterwork among others. They moved via small towns Mikulov and Valtice to the LedniceValtice landscape area. This unique artificial landscape is a part of the UNESCO world heritage. The excursion finished in Bořetice - the village of the year of 2005 and its famous Free Federal Republic of Kraví hora - a concentration of vine cellars offering Moravian vines to the tourists.

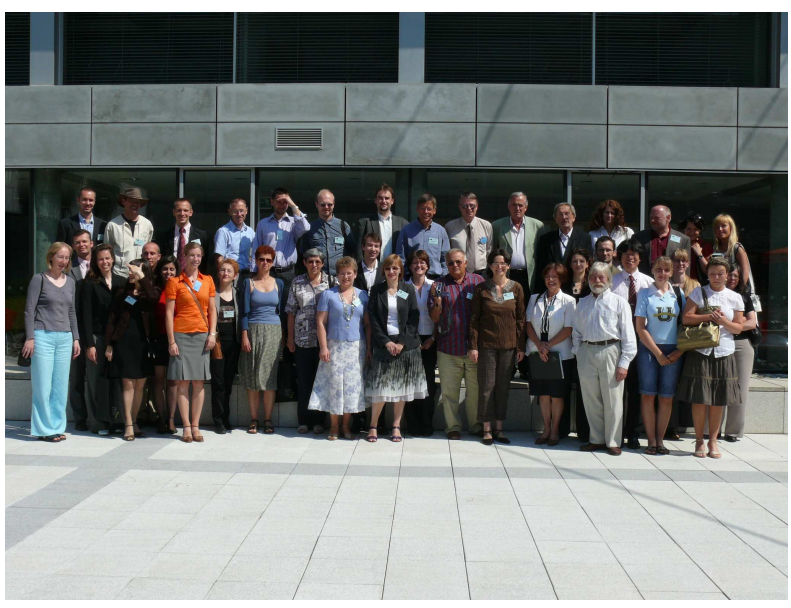

Fig 3. EURORURAL '08 participants

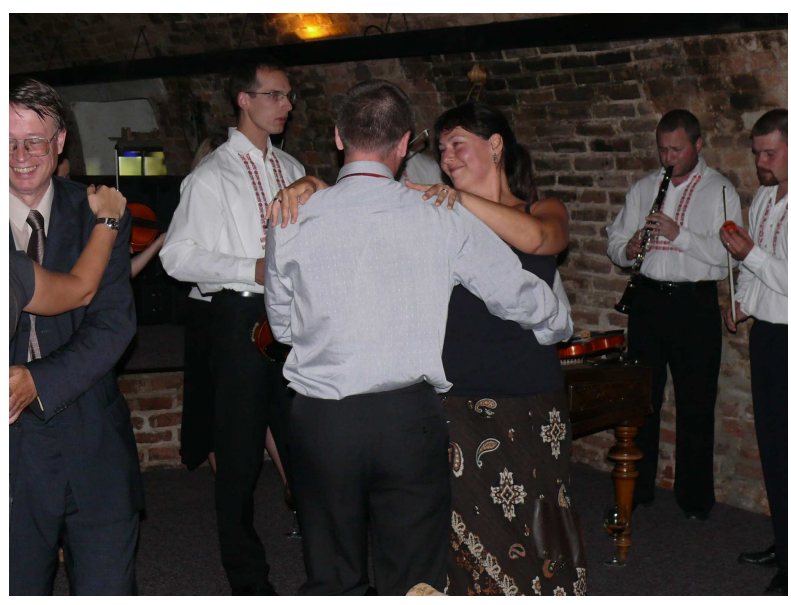

Fig 4. EURORURAL cultural part

Good organization level of the Conference was enabled with good technical and social equipment in the new " $Q$ " building of the MUAF. There was relatively enough time not only for presentations of papers but also for discussions. Social program gave afford occasions for consolidating and connecting personal contacts.

From the viewpoint of content, it is possible to divide all the papers more or less into three groups. First of them dealt with rural landscapes, next one with agricultural and other activities in the countryside including tourism and the last one concentrated itself on demographic, social and settlement problems. The whole Conference proceeded in English which disclosed not only possibilities but also limits of individual participants.

Besides the language problems, some case study approaches hanging in the air without appropriate theoretical framework belong to infrequent imperfections of the Conference. Nevertheless, just conferences enabling contacts among experts from different parts of Europe can assist by removing of problems and bring near the level of rural research in various countries. Relatively wide topic of the Conference contributed to the perception of the rurality from different viewpoints.

Successful organisation of the Conference in which took part a row of colleagues from MUAF erected a new challenge for the future. The reached standards have to be at least kept within the $2^{\text {nd }}$ Moravian rural conference which will take place in the summer of 2010.

\section{DERREG Project}

The project of the $7^{\text {th }}$ framework of EU with the title DERREG (Development of Europe's Rural Regions in the Era of Globalization) will run for 36 months since January 2009. The subtitle: An Interpretative Model for Better Anticipating and Responding to Challenges for Regional Development in an Evolving International Context. MUAF is responsible for dissemination of its results. EUROPEAN COUNTRYSIDE is supposed to be one of the tools in these efforts. 


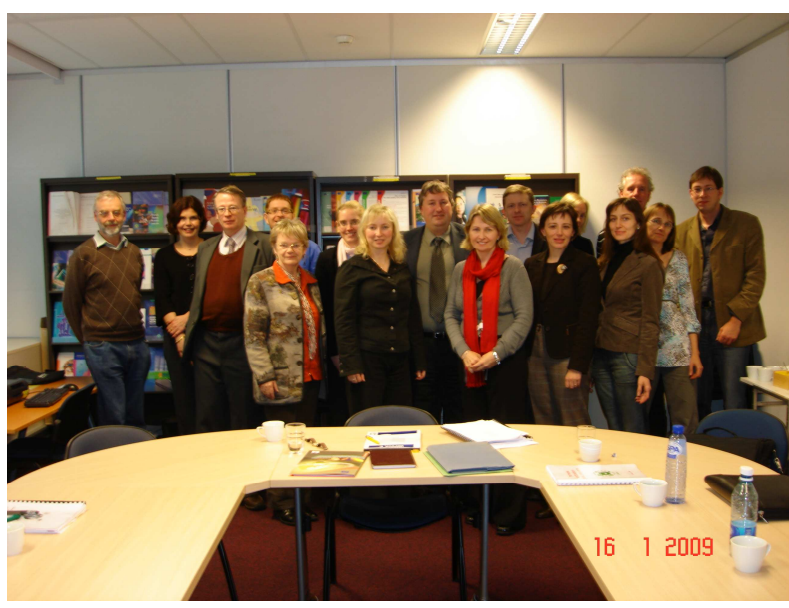

Fig 5. DERREG kick-off meeting

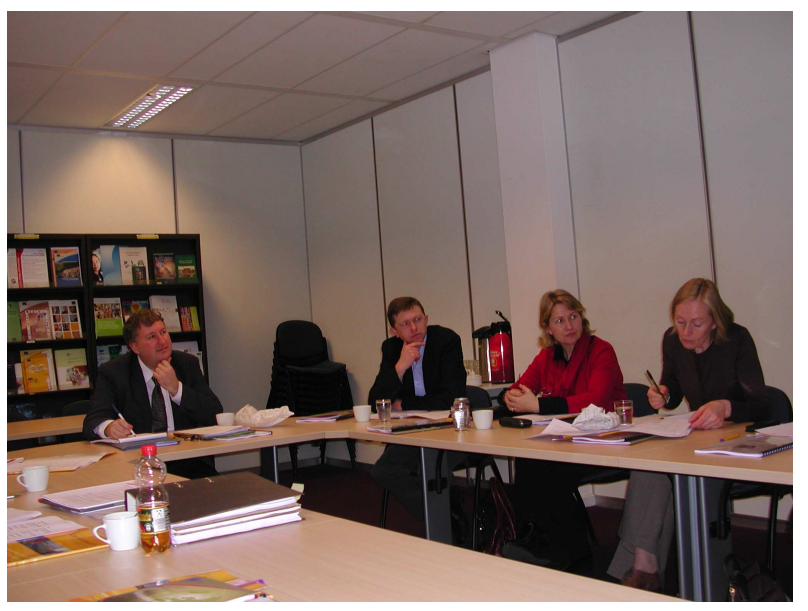

Fig 6. DERREG coordinator Michael Woods (left) with the Irish team

Globalization brings important social, economic, environmental and cultural changes. There are plenty of studies dealing with individual aspects of the process. The ambition of the DERREG project is to develop a relatively integrative approach. By the way, EUROPEAN COUNTRYSIDE has similar target.

The project involves four key themes (rural businesses, mobility of rural population, sustainable rural development, capacity building) and nine case study areas. The research will be based both on quantitative and qualitative approaches. Nine workplaces from 8 European countries are involved. M. Woods from the University of Wales in Aberystwyth is the co-ordinator.

\section{Next Steps}

There are following steps ahead of the EUROPEAN COUNTRYSIDE: We have to stabilize the activity of Advisory Board, Executive Team and Realization Group to find the most efficient modus of work. At the same time, we have to take a wide information and advertising action which will be directed to involve the Journal into scientific community and to attract the Journal for authors and readers. To gain sufficient predominance of articles over the minimum necessity to keep the Journal is the main precondition to improve quality of papers. It would enable no time pressure, to be able to react on remarks and suggestions and to improve individual articles by such a way.

The minimum extent is 5 papers (about 60 pages) per an issue, it means 20 papers per volume. But our concept does not know the maximum limit. The on-line way is in reality unlimited and the payment of papers by authors allows publish as many papers as prepared.

EUROPEAN COUNTRYSIDE is at disposal to all the experts who participate in research project, organize conferences, prepare theses or simply are interested in rural problems. We believe that the journal allows to make new contacts for exchange ideas, forming research teams and preparing events. 